\title{
Studies on the appearance of a hepatic copper-binding protein in normal and zinc-deficient rats
}

\author{
BY I. BREMNER AND N. T. DAVIES \\ Rowett Research Institute, Bucksburn, Aberdeen $A B 2{ }_{9} S B$ \\ (Received I6 October 1975 - Accepted 5 Fanuary 1976)
}

I. A study has been made by gel-filtration techniques of the soluble copper- and zincbinding proteins in rat liver after both intraperitoneal injection of $\mathrm{Cu}$ and dietary $\mathrm{Cu}$ supplementation.

2. Liver $\mathrm{Cu}$ and $\mathrm{Zn}$ concentrations increased after injection of $\mathrm{Cu}$, both metals accumulating in the cytosol, mainly in a fraction with an apparent molecular weight of about 12000 .

3. When $\mathrm{Zn}$-deficient rats were injected with $\mathrm{Cu}$, there was little change in liver $\mathrm{Zn}$ concentration and the occurrence of $\mathrm{Cu}$ in the low-molecular-weight form (about 12000 ) was more transient. At most periods after injection, $\mathrm{Cu}$ accumulated mainly in a fraction with a molecular weight greater than 65000 .

4. When the rats were Cu-loaded by dietary supplementation, virtually no $\mathrm{Cu}$ or $\mathrm{Zn}$ was found in the low-molecular-weight form in $\mathrm{Zn}$-deficient rats, although they were found in the $\mathrm{Zn}$-supplemented animals.

5. The results suggest that $\mathrm{Zn}$ is essential for the accumulation of $\mathrm{Cu}$ in this form, but not for $\mathrm{Cu}$ to stimulate production of the metal-binding protein by a process requiring active protein synthesis.

The results of previous studies on ruminant liver suggested that the occurrence of a metallothionein-like, copper- and zinc-binding fraction was related to the $\mathrm{Zn}$, but not $\mathrm{Cu}$, content of the liver, although both elements apparently competed for binding sites on the protein (Bremner \& Marshall, r974a,b). This relationship was not found in normal pig liver, as the amount of $\mathrm{Cu}$ or $\mathrm{Zn}$ present in this form was dependent only on the liver concentration of that metal, with no evidence of competitive binding (Bremner, I976; Bremner \& Young, unpublished results). In the livers from $\mathrm{Zn}$-deficient pigs, however, both the $\mathrm{Cu}$ - and $\mathrm{Zn}$-proteins were absent, regardless of the hepatic $\mathrm{Cu}$ content, implying that a minimal amount of $\mathrm{Zn}$ was in some way essential for the production or accumulation of the metalbinding protein.

Studies of the effects of $\mathrm{Zn}$ injection in rats has confirmed that $\mathrm{Zn}$ can indeed promote the synthesis de novo or the stabilization of hepatic metallothionein (Bremner \& Davies, 1975). Comparable studies have now been made in both normal and $\mathrm{Zn}$-deficient rats on the appearance of an analogous hepatic $\mathrm{Cu}$-binding fraction after a single $\mathrm{Cu}$ injection or after long-term dietary $\mathrm{Cu}$ supplementation. The results indicate that although $\mathrm{Zn}$ is not essential for $\mathrm{Cu}$ to stimulate production of this $\mathrm{Cu}$-binding hepatic protein, it is required for accumulation of $\mathrm{Cu}$ in this form. A preliminary report of some of this work has been published (Bremner \& Davies, I974). 
EXPERIMENTAL

Animals and treatment

Male Hooded Lister rats of the Rowett Institute strain were used. They were caged individually and maintained on the semi-synthetic diet of Williams \& Mills (1970), which contained $40 \mathrm{mg} \mathrm{Zn}$ and $25 \mathrm{mg} \mathrm{Cu} / \mathrm{kg}$. When $\mathrm{Zn}$-deficient or Cu-loaded rats were required, the dietary concentrations were changed to $<\mathrm{I} \mathrm{mg} \mathrm{Zn}$ and 200 or $500 \mathrm{mg} \mathrm{Cu} / \mathrm{kg}$ respectively.

\section{Expt I. Effects of injection of $\mathrm{Cu}$ on hepatic distribution of $\mathrm{Cu}$ and $\mathrm{Zn}$}

$\mathrm{Zn}$-deficient rats $\left(\mathrm{I}_{5} \mathrm{\circ} \mathrm{g}\right.$ ) were obtained by transferring rats, aged about $60 \mathrm{~d}$, to the low- $\mathrm{Zn}$ diet $2 \mathrm{I}$ d before the start of the experiment. Several groups of $\mathrm{Zn}$ supplemented $(15 \circ \mathrm{g}$ ) or $\mathrm{Zn}$-deficient rats, each group containing at least four animals, were injected intraperitoneally with 100 or $300 \mu \mathrm{g} \mathrm{Cu}$ (as cupric sulphate in a solution containing $9 \mathrm{~g}$ sodium chloride/ 1 ). They were killed by a blow on the head at intervals from $0.5 \mathrm{~h}$ to $8 \mathrm{~d}$ after the injection, and their livers were removed immediately. Livers were also collected from groups of $\mathrm{Zn}$-supplemented and $\mathrm{Zn}$ deficient control rats which had not been injected with $\mathrm{Cu}$.

\section{Expt 2. Effects of $Z n$ deficiency on hepatic $C u$ distribution of $C u$-loaded rats}

Forty-eight rats $(75-85 \mathrm{~g})$ were allocated at random to three groups, each of sixteen animals, which were given: group $\mathrm{A}$, the low- $\mathrm{Zn}$, high-Cu diet, ad lib.; group $\mathrm{B}$, the $\mathrm{Zn}$-supplemented, high-Cu diet, pair-fed to group $\mathrm{A}$; group $\mathrm{C}$, the $\mathrm{Zn}$-supplemented, high- $\mathrm{Cu}$ diet, ad lib. The $\mathrm{Cu}$ content of the diet was increased from 200 to $500 \mathrm{mg} / \mathrm{kg}$ after 5 weeks. Four rats from each group were killed after $3,5,8$ and to weeks on the experimental diets and their livers removed immediately.

\section{Fractionation of livers}

Samples of each liver were freeze-dried, digested with conc. nitric acid-conc. perchloric acid-conc. sulphuric acid $(5: 2: \mathrm{I}, \mathrm{v} / \mathrm{v})$, and their $\mathrm{Cu}$ and $\mathrm{Zn}$ contents determined by atomic absorption spectrophotometry.

The remainders of each liver within the appropriate groups were combined, homogenized with 2.5 vol. (v/w) $0.01 \mathrm{M}$-Tris-acetate buffer, $\mathrm{pH} 7.4$, centrifuged at $100000 \mathrm{~g}$ for $\mathrm{I} \mathrm{h}$, and the supernatant fractions fractionated on Sephadex G-75 (Pharmacia Ltd, Uppsala, Sweden) as described previously (Bremner \& Marshall, 1974a).

\section{RESULTS}

\section{Expt I. Effect of injection of $\mathrm{Cu}$ on hepatic distribution of $\mathrm{Cu}$ and $\mathrm{Zn}$}

When twelve $\mathrm{Zn}$-supplemented rats were injected with roo $\mu \mathrm{g} \mathrm{Cu}$ and killed after $8 \mathrm{~h}$, variable increases occurred in the hepatic concentrations of both $\mathrm{Cu}$ and $\mathrm{Zn}$. The final concentrations ( $\mu \mathrm{g} / \mathrm{g}$ dry matter (DM)) were: $\mathrm{Cu} 40 \cdot 8 \pm 3 \cdot 7, \mathrm{Zn}$ I I I $4 \pm 4 \cdot 0$; control values for non-injected rats were $22 \cdot 7 \pm \mathrm{x} \cdot 6$ and $93 \cdot 3 \pm 2 \cdot 7$ for $\mathrm{Cu}$ and $\mathrm{Zn}$ 


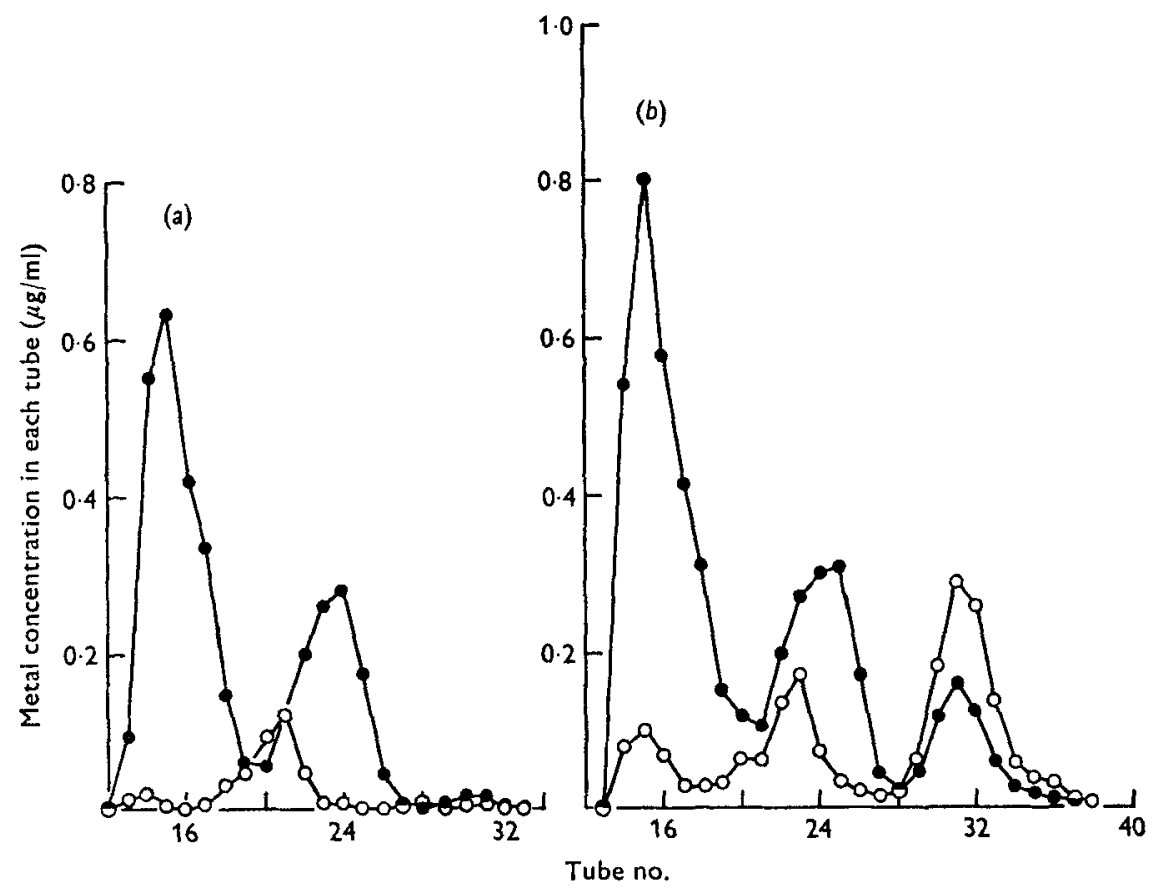

Fig. I. Expt I. Fractionation on Sephadex G-75 of the supernatant fractions from the livers of $(a)$ control, zinc-supplemented rats and $(b) \mathrm{Zn}$-supplemented rats injected with $300 \mu \mathrm{g}$ copper (as cupric sulphate) $8 \mathrm{~h}$ previously. The concentrations $(\mu \mathrm{g} / \mathrm{ml})$ of $\mathrm{Cu}(\mathrm{O})$ and of $\mathrm{Zn}(\odot)$ in each tube are shown. Fractions $\mathrm{I}-3$ were contained in tubes $12-18,19-27$ and 28-37 respectively, and each tube contained $5 \mathrm{ml}$ eluate.

respectively. There was a significant relationship between the hepatic concentrations of the two metals in the injected rats, as expressed by the equation:

$$
Y_{1}=0.8 \mathrm{r} x_{1}-49.5 \text { (SE of regression coefficient } 0.14 \text { ), }
$$

where $Y_{1}$ and $x_{1}$ are the liver concentrations ( $\left.\mu \mathrm{g} / \mathrm{g} \mathrm{DM}\right)$ of $\mathrm{Cu}$ and $\mathrm{Zn}$ respectively.

The livers were allocated into five groups, according to their $\mathrm{Cu}$ and $\mathrm{Zn}$ contents and the distribution of the metals in the cytosol was determined by gel filtration on Sephadex G-75. Typical separations for livers from the injected rats with the highest $\mathrm{Cu}$ contents, and from control rats are shown in Fig. I. Three main fractions, I-3, were collected as described previously (Bremner $\&$ Davies, 1975), with approximate molecular weights of $>65000,35000$ and 12000 , as estimated from their elution volumes from the column. The most obvious effect of $\mathrm{Cu}$ injection was to increase the amount of $\mathrm{Cu}$, and to a lesser extent of $\mathrm{Zn}$, present in fraction 3 and of $\mathrm{Cu}$ in fraction $\mathrm{I}$. There was occasionally a slight increase in the $\mathrm{Zn}$ content of fraction $\mathrm{I}$ but little change in metal-binding contents of fraction 2. It was found that the $\mathrm{Cu}$ distribution was not greatly affected by the liver $\mathrm{Cu}$ content, as about half the total $\mathrm{Cu}$ occurred in fraction 3 in each group of the $\mathrm{Cu}$-injected rats.

In view of the relationship between metal-binding in fraction 3 and liver $\mathrm{Zn}$ content found in previous studies (Bremner \& Marshall, 1974b), a closer study was 


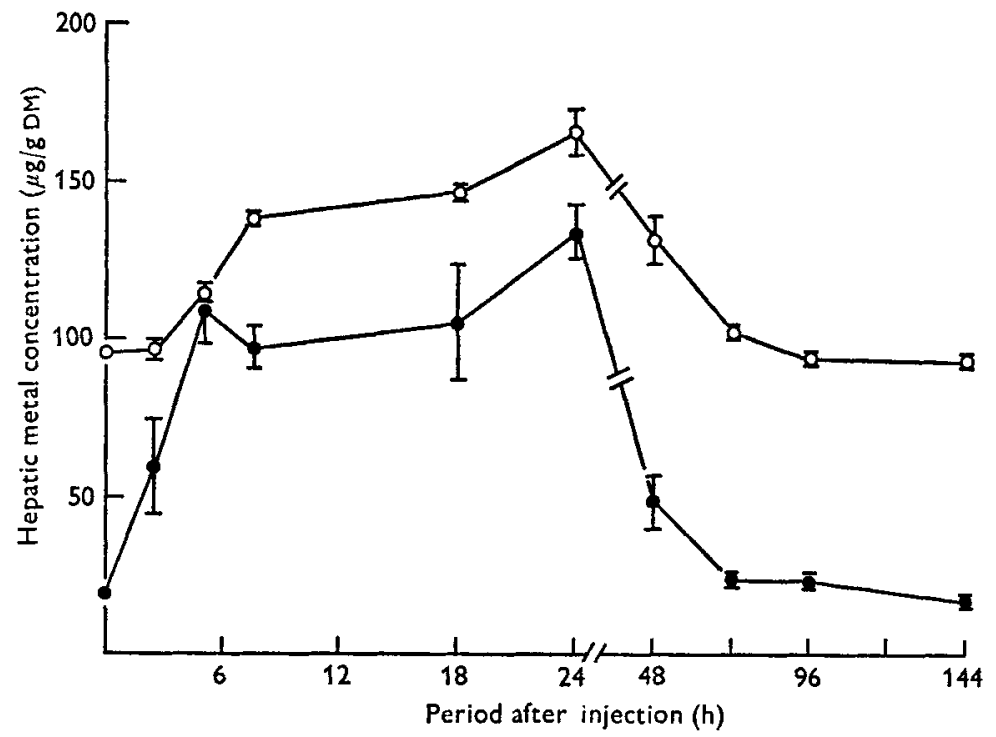

Fig. 2. Expt I. Change in liver copper (O) and zinc (O) concentrations $(\mu \mathrm{g} / \mathrm{g}$ dry matter (DM)) of groups of five $\mathrm{Zn}$-supplemented rats with period (h) after intraperitoneal injection of $300 \mu \mathrm{g} \mathrm{Cu}$ (as cupric sulphate).

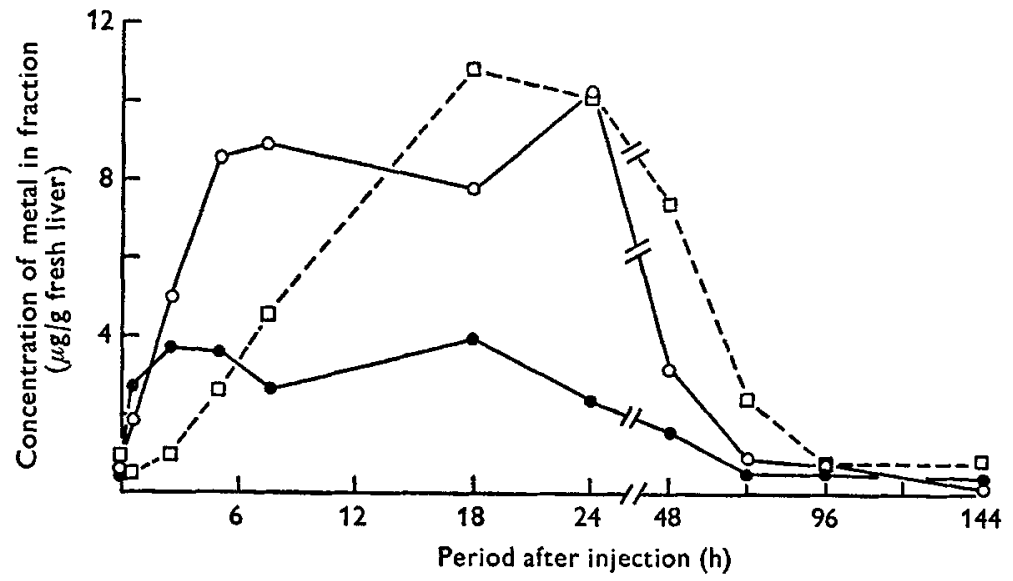

Fig. 3. Expt 1 . Changes in the distribution of copper and zinc in fractions from livers of groups of five $\mathrm{Zn}$-supplemented rats with period (h) after intraperitoneal injection of $300 \mu \mathrm{g} \mathrm{Cu}$ (as cupric sulphate). Liver homogenates were centrifuged and then fractionated on Sephadex G-75. The concentrations ( $\mu \mathrm{g} / \mathrm{g}$ fresh liver) of $\mathrm{Cu}(O)$ and $\mathrm{Zn}(\square)$ in fraction 3 and of $\mathrm{Cu}$ in fraction I (O) are shown; for details of fractions, see Fig. I.

made in fifty-five rats of the time-course of changes in the hepatic concentration and distribution of $\mathrm{Cu}$ and $\mathrm{Zn}$ after injection of $300 \mu \mathrm{g} \mathrm{Cu}$. Total hepatic $\mathrm{Cu}$ concentration increased rapidly in the first $5 \mathrm{~h}$ from about 16 to $\mathrm{I} 10 \mu \mathrm{g} / \mathrm{g} \mathrm{DM}$, then more slowly to a maximum of $\mathrm{I} 35 \mu \mathrm{g} / \mathrm{g}$ DM at $24 \mathrm{~h}$ (Fig. 2). It decreased thereafter and by $3 \mathrm{~d}$ after injection was at 'near-normal' levels. Liver $\mathrm{Zn}$ concentration was unchanged in the first $2.5 \mathrm{~h}$ at approximately $95 \mu \mathrm{g} / \mathrm{g} \mathrm{DM}$, increased to I I $5 \mu \mathrm{g} / \mathrm{g} \mathrm{DM}$ by $5 \mathrm{~h}$, and increased steadily thereafter to a maximum of $166 \mu \mathrm{g} / \mathrm{g}$ DM at $24 \mathrm{~h}$ after 
injection. Although the maximum concentrations of $\mathrm{Zn}$ and $\mathrm{Cu}$ were attained at the same interval after injection the subsequent decrease in $\mathrm{Zn}$ concentration was slower than that for $\mathrm{Cu}$. Liver $\mathrm{Zn}$ content had returned to 'near-normal' values $3^{-4} \mathrm{~d}$ after injection. There was no consistent significant relationship between the $\mathrm{Cu}$ and $\mathrm{Zn}$ content of the livers at any interval after injection.

The distribution of soluble $\mathrm{Cu}$ and $\mathrm{Zn}$ within fractions $\mathrm{I}$ and 3 is shown in Fig. 3 . As only slight increases were found in the total amount of $\mathrm{Cu}$ present in fraction 2, usually about $2 \cdot 9 \mu \mathrm{g} / \mathrm{g}$ fresh liver, these are not shown. The amount of $\mathrm{Cu}$ in fraction I increased almost tenfold within $2.5 \mathrm{~h}$ to $3.7 \mu \mathrm{g} \mathrm{Cu} / \mathrm{g}$ fresh liver, but little further change occurred until $18 \mathrm{~h}$ after injection, when the concentration started to decrease. Incorporation of $\mathrm{Cu}$ into fraction 3 was almost as rapid, and high concentrations were maintained between 5 and $24 \mathrm{~h}$ when about $60 \%$ of the soluble $\mathrm{Cu}$ was in this form. The $\mathrm{Cu}$ content of fraction 3 decreased from 10.2 to $3.2 \mu \mathrm{g} / \mathrm{g}$ fresh liver between $\mathrm{I}$ and $2 \mathrm{~d}$ after injection, and was at 'near-normal' levels by 3-4 d. The amount of $\mathrm{Zn}$ in fraction 3 was unchanged until about $2.5 \mathrm{~h}$ after injection, but increased thereafter up to a maximum of $10.8 \mu \mathrm{g} / \mathrm{g}$ fresh liver at $\mathrm{I} 8 \mathrm{~h}$ after injection, whereupon it decreased slowly over the next $3 \mathrm{~d}$ to normal levels. The concentrations of $\mathrm{Zn}$ in fractions $\mathrm{I}$ and 2 were relatively unchanged throughout at about $I \mathrm{I} \cdot 7$ and $6 \cdot 0 \mu \mathrm{g} / \mathrm{g}$ fresh liver respectively.

The amount of $\mathrm{Cu}$ present in fraction 3 in fifteen groups of livers at $5 \mathrm{~h}-3 \mathrm{~d}$ after injection of 100 or $300 \mu \mathrm{g} \mathrm{Cu}$ was found to be a function of the liver $\mathrm{Cu}$ content. This could be expressed by the equation:

$$
Y_{2}=0.35 x_{2}-1.28 \text { (SE of regression coefficient } 0.032, r 0.95 \text { ), }
$$

where $Y_{2}$ and $x_{2}$ are the concentrations of $\mathrm{Cu}(\mu \mathrm{g} / \mathrm{g}$ fresh liver) in fraction 3 and the whole liver respectively.

The relationship between the concentration of $\mathrm{Zn}$ in whole liver $\left(x_{3}\right)$ and fraction 3 $\left(Y_{3}\right)$ for all rats injected with $300 \mu \mathrm{g} \mathrm{Cu}$ is given by the equation:

$$
Y_{3}=0.54 x_{3}-{ }_{15} .8 \quad \text { (SE of regression coefficient } 0.073, r 0.9 \mathrm{I} \text { ). }
$$

In an attempt to determine whether the increase in hepatic $\mathrm{Zn}$ concentration was essential for the appearance of $\mathrm{Cu}$ in fraction 3 , similar studies were done using forty-four $\mathrm{Zn}$-deficient rats. It was found that the hepatic $\mathrm{Cu}$ uptake after injection of $300 \mu \mathrm{g} \mathrm{Cu}$ (Fig. 4) was more rapid than in $\mathrm{Zn}$-supplemented rats (Fig. 2). Maximum $\mathrm{Cu}$ concentrations of $140 \mu \mathrm{g} / \mathrm{g}$ DM were reached within $7.5 \mathrm{~h}$ but these decreased thereafter and the concentrations at 24 and $48 \mathrm{~h}$ after injection were 70 and $45 \%$ of the maximum respectively. Normal values were restored $3 \mathrm{~d}$ after injection. Although slight increases in hepatic $\mathrm{Zn}$ content of about 30 and $20 \mu \mathrm{g} / \mathrm{g}$ DM occurred after 7.5 and $18 \mathrm{~h}$, at all other intervals after injection $\mathrm{Zn}$ contents were similar to those in the non-injected rats.

In contrast to the immediate appearances of $\mathrm{Cu}$ in fraction 3 in $\mathrm{Zn}$-supplemented rats, the first appearance of $\mathrm{Cu}$ in this fraction in the $\mathrm{Zn}$-deficient animals did not occur until $5 \mathrm{~h}$ after injection of $\mathrm{Cu}$, when $28 \%$ of the soluble $\mathrm{Cu}$ was present in this form (Fig. 5). This proportion increased to $50 \%$, equivalent to $10 \mu \mathrm{g} \mathrm{Cu} / \mathrm{g}$ 


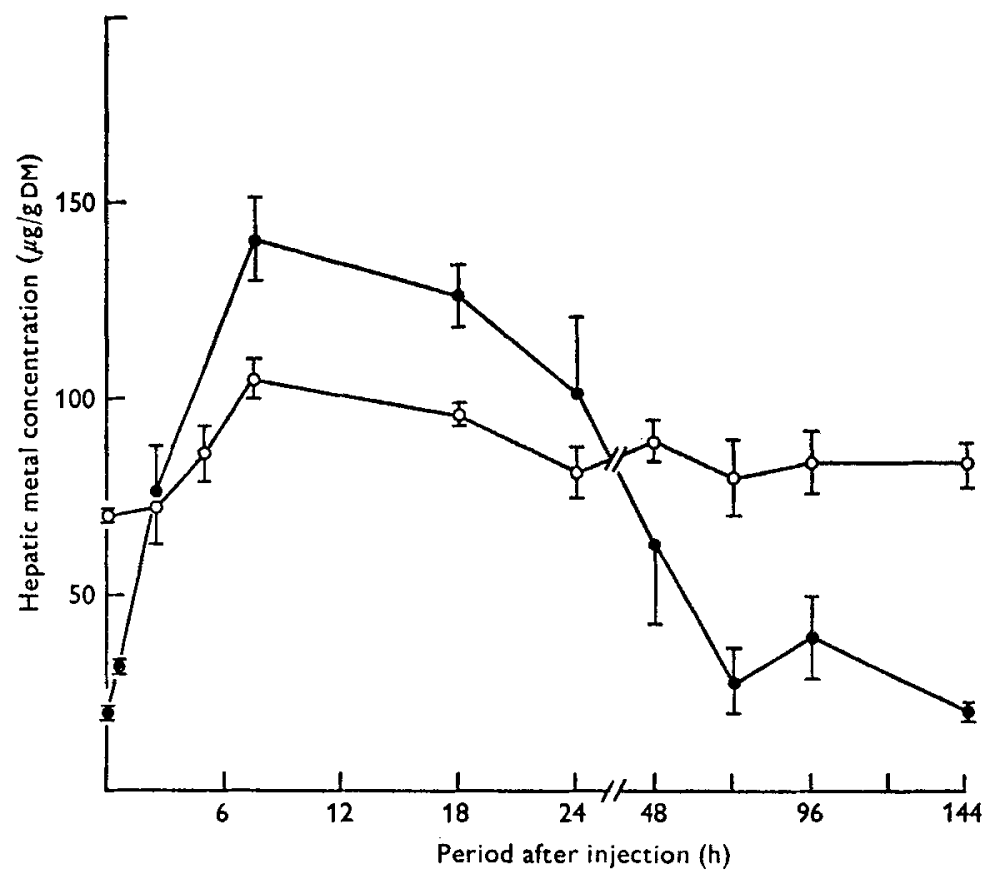

Fig. 4. Expt I. Changes in the liver copper (O) and zinc (O) concentrations ( $\mu$ g/g dry matter (DM)) of groups of four $\mathrm{Zn-deficient} \mathrm{rats} \mathrm{with} \mathrm{period} \mathrm{(h)} \mathrm{after} \mathrm{intraperitoneal} \mathrm{injection}$ of $300 \mu \mathrm{g} \mathrm{Cu}$ (as cupric sulphate).

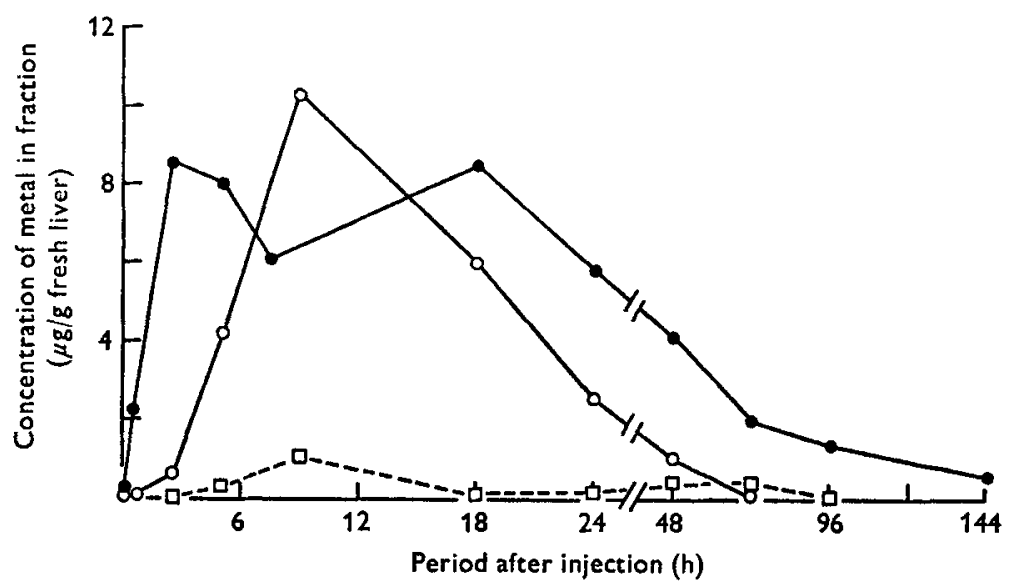

Fig. 5. Expt I. Changes in the distribution of copper and zinc in fractions from livers of groups of four $\mathrm{Zn}$-deficient rats with period (h) after intraperitoneal injection of $300 \mu \mathrm{g} \mathrm{Cu}$ (as cupric sulphate). Liver homogenates were centrifuged and then fractionated on Sephadex G-75. Concentrations ( $\mu \mathrm{g} / \mathrm{g}$ fresh liver) of $\mathrm{Cu}(\mathrm{O})$ and $\mathrm{Zn}(\square)$ in fraction 3 and of $\mathrm{Cu}$ in fraction $I(\Theta)$ are shown; for details of fractions, see Fig. I. 
Table 1. Expt I. Effect of simultaneous intraperitoneal injection of cycloheximide ( $2 \mathrm{mg} / \mathrm{kg})$ and copper $(3 \circ 0 \mathrm{~g})$ on hepatic Cu distribution in zinc-deficient rats

(Values based on a single fractionation on Sephadex G-75 of combined livers from four rats/treatment)

reatment

Control

$+\mathrm{Cu}$ alone*

$+\mathrm{Cu}+$ cycloheximide*

\begin{tabular}{|c|c|c|c|}
\hline \multicolumn{4}{|c|}{ Concentration of $\mathrm{Cu}(\mu \mathrm{g} / \mathrm{g}$ fresh liver $)$} \\
\hline Whole liver & Fraction $\mathrm{rt}$ & Fraction $2 \dagger$ & Fraction $3 \dagger$ \\
\hline $4 \cdot 5$ & 0.4 & $2 \cdot x 6$ & 0.01 \\
\hline $33 \cdot 3$ & $7 \cdot 4$ & 4.55 & $9 \cdot I$ \\
\hline 26.8 & $I I \cdot I$ & $2 \cdot 68$ & 0.9 \\
\hline
\end{tabular}

* Rats were killed $5 \mathrm{~h}$ after injection.

$\uparrow$ For details of fractionation procedure, see p. I02 and Fig. I.

fresh liver, over the next $2.5 \mathrm{~h}$ but decreased thereafter, the concentration at $24 \mathrm{~h}$ being only $25 \%$ of the maximum. Compared with the Zn-supplemented rats, proportionally more of the $\mathrm{Cu}$ was therefore present in fraction $\mathrm{I}$ at all intervals after injection, and especially in the periods $0-5$ and $18-72 \mathrm{~h}$ after injection of $\mathrm{Cu}$. The amounts of $\mathrm{Cu}$ in fraction $2(2.7 \pm 0.2 \mu \mathrm{g} / \mathrm{g}$ fresh liver) and of $\mathrm{Zn}$ in fractions I $(10.7 \pm 0.4 \mu \mathrm{g} / \mathrm{g}$ fresh liver) and $2(4.2 \pm 0.2 \mu \mathrm{g} / \mathrm{g}$ fresh liver) were relatively unchanged at all intervals after injection. A slight increase in the concentration of $\mathrm{Zn}$ in fraction 3 occurred after $7.5 \mathrm{~h}$.

The concentration of $\mathrm{Cu}$ in fraction 3 in both $\mathrm{Zn}$-supplemented and $\mathrm{Zn}$-deficient rats decreased at an exponential rate after maximum concentrations had been reached. This could be expressed by the equations:

for $\mathrm{Zn}$-supplemented rats: $Y_{1}=\mathrm{x} \cdot 23-0.015 x$ (SE of regression coefficient 0.0017 ), for Zn-deficient rats: $\quad Y_{2}=\mathrm{x} \cdot 29-0.030 x$ (SE of regression coefficient 0.0046 ), where $Y_{1}$ and $Y_{2}$ are $\log _{10}$ concentration of $\mathrm{Cu}$ in fraction $3(\mu \mathrm{g} / \mathrm{g}$ fresh liver) and $x$ is the period (h) after $\mathrm{Cu}$ injection. As the slopes of these lines are significantly different $(P<0.025)$, it is clear that $\mathrm{Cu}$ disappears more rapidly from fraction 3 in the $\mathrm{Zn}$-deficient rat, the half-life being about $10 \mathrm{~h}$ compared with $20 \mathrm{~h}$ in the Zn-supplemented animals.

When $\mathrm{Zn}$-deficient rats were simultaneously injected with cycloheximide $(2 \mathrm{mg} / \mathrm{kg}$ body-weight) and $\mathrm{Cu}(300 \mu \mathrm{g})$ and killed after $5 \mathrm{~h}$, the incorporation of $\mathrm{Cu}$ into fraction 3 was reduced by $90 \%$ (Table $\mathrm{I}$ ). The hepatic accumulation of $\mathrm{Cu}$ was by comparison only slightly affected, being $75 \%$ of that in the non-cycloheximidetreated animals. The dose of cycloheximide used was found in separate studies (Davies, Bremner \& Mills, I973) to be sufficient to inhibit $\left[{ }^{44} \mathrm{C}\right] l y s i n e$ incorporation into total liver protein by $90 \%$.

\section{Expt 2. Effects of $\mathrm{Zn}$ deficiency on hepatic $\mathrm{Cu}$ distribution of $\mathrm{Cu}$-loaded rats}

Despite the high $\mathrm{Cu}$ contents of the diets, increases in liver $\mathrm{Cu}$ content were usually small compared with those resulting from injection of $\mathrm{Cu}$. There were no obvious changes in metal distribution in the cytosol within treatment groups when 


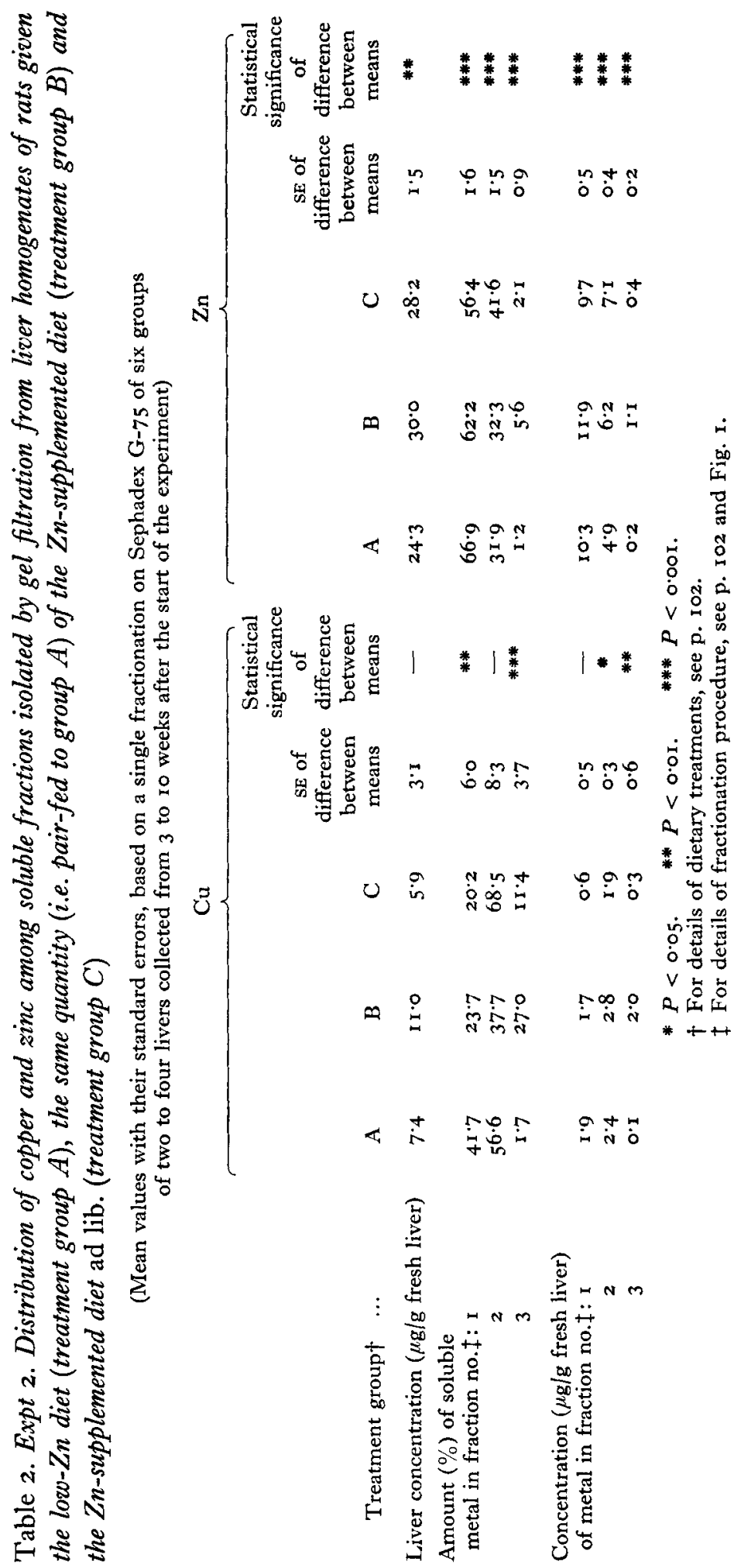


liver samples were analysed $3^{-10}$ weeks after the start of the experiment, and consequently all results are presented together (Table 2 ).

The most significant finding was the virtual absence of $\mathrm{Cu}$ and $\mathrm{Zn}$ from fraction 3 in the livers from the $\mathrm{Zn}$-deficient rats, with less than $2 \%$ of the soluble $\mathrm{Cu}$ in this form compared with nearly $30 \%$ in the pair-fed, $\mathrm{Zn}$-supplemented rats. $\mathrm{Cu}$ was evenly distributed between fractions $I$ and 3 in the latter animals, whereas in the livers from the $\mathrm{Zn}$-supplemented rats fed ad lib. there was less $\mathrm{Cu}$ in fraction 3 . The amount of $\mathrm{Cu}$ in fraction $\mathrm{2}$ tended to be relatively constant and independent of liver $\mathrm{Cu}$ content within treatment groups, and usually accounted for about $30 \%$ of the total $\mathrm{Cu}$ in the liver.

The only major change in the distribution of $\mathrm{Zn}$ was the increased concentration in fraction 3 of the pair-fed, $\mathrm{Zn}$-supplemented rats.

\section{DISCUSSION}

The virtual absence of $\mathrm{Cu}$ or $\mathrm{Zn}$ from fraction 3 of the livers of the $\mathrm{Zn}$-deficient rats given the high-Cu diets, regardless of the liver $\mathrm{Cu}$ content, supports the view (Bremner \& Marshall, 1974b; Bremner, 1976) that $\mathrm{Zn}$ must play an essential part in the production of this group of metal-binding proteins. Although these results could indicate that $\mathrm{Cu}$ is incapable of stimulating the production of these proteins in a low- $\mathrm{Zn}$ situation, the results of acute studies involving injection of $\mathrm{Cu}$ suggest that this is not so, as the Cu-binding fractions produced in $\mathrm{Zn}$-supplemented and $\mathrm{Zn}$-deficient rats were apparently the same. However, there were marked differences in the distribution of $\mathrm{Cu}$ between fractions $\mathrm{I}$ and 3 in the two groups of rats, especially in the persistance of $\mathrm{Cu}$ in fraction 3 after maximum concentrations had been reached. The more rapid removal of $\mathrm{Cu}$ from this form when $\mathrm{Zn}$ is absent, as in the $\mathrm{Zn}$-deficient rats, suggests that the presence of $\mathrm{Zn}$ may inhibit the degradation of the protein. The absence of hepatic $\mathrm{Cu}$ from fraction 3 in the $\mathrm{Zn}$-deficient rats given the dietary $\mathrm{Cu}$ supplement could then be a consequence of the decreased stability of the protein in the absence of additional $\mathrm{Zn}$.

Although this can only be unequivocally established by comparison of the turnover rates of the protein in the presence and absence of $\mathrm{Zn}$, it is recognized that the catabolism of many proteins is affected by the supply of various factors which bind to them (Goldberg \& Dice, 1974). For example, the susceptibility of superoxide dismutase ( $E C$ I.I 5.I.I) to carboxypeptidase $(E C 3.4 .2 .3)$ digestion in vitro is dependent on the $\mathrm{Zn}$ content of the enzyme (Rotilio, Calabrese, Bossa, Barra, Agro $\&$ Mondovi, 1972), probably because of the role of $\mathrm{Zn}$ in maintaining the conformational stability of this and other $\mathrm{Zn}$ enzymes (Drum, Harrison, Li, Bethune \& Vallee, 1967). It seems possible that $\mathrm{Zn}$ could stabilize the hepatic $\mathrm{Cu}$-protein in fraction 3 in the same way, although at this stage it has yet to be unequivocally established whether $\mathrm{Cu}$ and $\mathrm{Zn}$ bind to the same protein.

A notable feature of the $\mathrm{Cu}$-injection studies with $\mathrm{Zn}$-supplemented rats is the close connexion between the increase in liver $\mathrm{Cu}$ and $\mathrm{Zn}$ concentrations. The source of this $\mathrm{Zn}$ is not known although it has been found (Bremner \& Davies, unpublished 
results) that its entry into the liver is not preceded by pancreatic accumulation, as it is after injection of sufficient $\mathrm{Zn}$ to produce similar changes in liver $\mathrm{Zn}$ content (Davies \& Bremner, 1974). The uptake of $\mathrm{Zn}$ into fraction 3 after injection of $\mathrm{Cu}$ is very similar to that which occurs after injection of cadmium (Nordberg, Piscator $\&$ Lind, I971; Webb, 1972) with resultant formation of metallothionein (Winge \& Rajagopalan, 1972). The hepatic responses to injection of $\mathrm{Cu}$ and $\mathrm{Cd}$ are also similar in that binding of these metals in fraction 3 is preceded to some extent by binding in fraction $\mathrm{I}$, and administration of cycloheximide inhibits the production of the metal-binding protein in fraction 3 without markedly reducing hepatic accumulation of $\mathrm{Cu}$ or $\mathrm{Cd}\left(\mathrm{Webb}, \mathbf{1 9 7 2}^{2}\right.$ ). In contrast there is no prior binding of $\mathrm{Zn}$ in fraction $\mathrm{I}$ after $\mathrm{Zn}$ injection (Bremner \& Davies, 1975), and inhibition of protein synthesis reduces both production of $\mathrm{Zn}$-thionein and hepatic accumulation of the metal (Davies et al. 1973; Richards \& Cousins, 1975).

The inhibitory effect of cycloheximide on the appearance of $\mathrm{Cu}$ in fraction 3 suggests either that the process is dependent on active protein synthesis by some inductive mechanism, or that $\mathrm{Cu}$ stabilizes a minor apoprotein which is rapidly turning over without necessarily influencing its synthesis de novo. Both explanations are contrary to the claim that the apoprotein is constitutively present in rat liver (Bloomer \& Sourkes, 1973). However, our findings that fraction 3 can contain an important $\mathrm{Cu}$-binding protein in rat liver, and our results from the time-course study of the appearance and disappearance of $\mathrm{Cu}$ from this fraction after $\mathrm{Cu}$ injections, are in general agreement with these of Bloomer \& Sourkes (1973). Terao \& Owen (1973) have reported that the greatest proportion of injected $\mathrm{Cu}$ appears in this fraction within $30 \mathrm{~min}$ and persists for only a few hours. However, they injected only tracer amounts of $\mathrm{Cu}$ as ${ }^{64} \mathrm{Cu}$ and it is possible that some isotopic exchange may have occurred.

The functional importance of the induced $\mathrm{Cu}$-protein has not yet been established, but it seems likely that it is primarily involved in the rapid hepatic uptake of $\mathrm{Cu}$, perhaps including removal of albumin-bound $\mathrm{Cu}$ (Marceau \& Aspin, 1973) and temporary storage and detoxication of $\mathrm{Cu}$ (Bremner \& Davies, 1974). As there are no reports of important disturbances in $\mathrm{Cu}$ metabolism of $\mathrm{Zn}$-deficient rats, in which no hepatic $\mathrm{Cu}$ occurs in fraction 3 , it would appear that the hepatic protein is not essential for $\mathrm{Cu}$ to fulfil its metabolic functions.

Hepatic $\mathrm{Cu}$-proteins of similar molecular weight to fraction 3 have been isolated from humans (Shapiro, Morell \& Scheinberg, 196I), cattle (Evans, Majors \& Cornatzer, 1970) and ruminants (Bremner \& Marshall, 1974b). In the latter instance competitive binding between $\mathrm{Cu}$ and $\mathrm{Zn}$ was found to occur and the metal-binding protein was characterized as metallothionein. More recently it has been found that a range of mixed $\mathrm{Cu}-\mathrm{Zn}$-thioneins also occurs in the livers of pigs given high-Cu diets (Bremner \& Young, unpublished results) and there is some indirect evidence that in Expt 2 at least some of the $\mathrm{Cu}$ in rat liver was in this form. When the liver $\mathrm{Zn}$ concentration in the rat is increased, as by injection of $\mathrm{Zn}$ or restriction of food intake, about $75 \%$ of the additional $\mathrm{Zn}$ generally occurs as $\mathrm{Zn}$-thionein (Bremner \& Davies, I975). However, this proportion was considerably reduced in the partially- 
starved, pair-fed control rats given $\mathrm{Cu}$, especially at the higher liver $\mathrm{Cu}$ contents, suggesting that $\mathrm{Zn}$ may have been isomorphously replaced on the thionein-protein by $\mathrm{Cu}$, so that at least some of the $\mathrm{Cu}$ in fraction 3 is probably present as $\mathrm{Cu}$-thionein. It has been reported also that $\mathrm{Cu}$ frequently occurs as a minor component in renal metallothionein (Pulido, Kägi \& Vallee, 1966) and it has been suggested that the particulate $\mathrm{Cu}$-protein of neonatal liver may be a polymeric, $\mathrm{Cu}$-rich species of metallothionein (Porter, I974; Rupp \& Weser, 1974).

It is far from certain, however, that this represents the only form of $\mathrm{Cu}$ in fraction 3 . Since this work was completed, a $\mathrm{Cu}$-protein which differs in several respects from metallothionein has been isolated from the livers of $\mathrm{Cu}$-injected rats (Winge, Premakumar, Wiley \& Rajagopalan, 1975). So far this protein, Cu-chelatin, has only been obtained after acute administration of $\mathrm{Cu}$, and it will be of considerable interest to determine whether it occurs also in normal physiological situations.

Important differences occur between ruminants, pigs and rats in the proportion of the hepatic $\mathrm{Cu}$ which is normally found in fraction 3 , and in the influence thereon of liver $\mathrm{Zn}$ content. In all species, negligible amounts of $\mathrm{Cu}$ or $\mathrm{Zn}$ occur in this form when the animals are $\mathrm{Zn}$-deficient and on long-term dietary experiments (Bremner \& Marshall, I974a; Bremner, 1976). In Zn-supplemented pigs fraction 3 usually accounts for $80 \%$ of the $\mathrm{Cu}$ in the cytosol, whereas in ruminants the proportion can vary from $\mathrm{I}_{5}$ to $70 \%$ depending on liver $\mathrm{Zn}$ content. In the rat livers proportionately less $\mathrm{Cu}$ occurred in this fraction than in the pig livers, but this was increased when liver $\mathrm{Zn}$ content increased, as after restriction of food intake. Less is known of species differences in response to injection of $\mathrm{Cu}$. Preliminary studies, involving serial liver biopsies of both $\mathrm{Zn}$-deficient and $\mathrm{Zn}$-supplemented sheep which were injected with $\mathrm{Cu}$, indicate that production of the $\mathrm{Cu}$-binding protein in fraction 3 is independent of $\mathrm{Zn}$ status but that, as in the rat, persistence of $\mathrm{Cu}$ in this form is reduced in the $\mathrm{Zn}$-deficient animal (Bremner, unpublished results).

These results indicate that considerable differences may occur in the response of animals to acute and long-term exposure to heavy metals, and that the effects can be markedly influenced by the status of the animal with respect to other essential metals. If similar changes also occur in other tissues it is possible that these metalbinding proteins are intimately involved in the mechanism of the interaction between $\mathrm{Cu}$ and $\mathrm{Zn}$.

It has now been proved (Bremner \& Young, unpublished results) that the $\mathrm{Cu}$ in fraction 3 is present as metallothionein.

\section{REFERENCES}

Bloomer, L. C. \& Sourkes, 'T. L. (1973). Biochem. Med. 8, 78.

Bremner, I. (1976). Br. F. Nutr. 35, 245.

Bremner, I. \& Davies, N. T. (1974). Biochem. Soc. Trans. 2, 425.

Bremner, I. \& Davies, N. T. (1975). Biochem. f. 149, 733.

Bremner, I. \& Marshall, R. B. (1974a). Br. F. Nutr. 32, 283.

Bremner, I. \& Marshall, R. B. (1974b). Br. F. Nutr. 32, 293.

Davies, N. T. \& Bremner, I. (1974). Biochem. Soc. Trans. 2, 654.

Davies, N. T., Bremner, I. \& Mills, C. F. (1973). Biochem. Soc. Trans. 1, 985. 
Drum, D. E., Harrison, J. H., Li, T. K., Bethune, J. L. \& Vallee, B. L. (1967). Proc. natn. Acad. Sci. U.S.A. $57, \mathrm{I} 434$.

Evans, G. W., Majors, P. F. \& Cornatzer, W. E. (1970). Biochem. biophys. Res. Commun. 40, II 42.

Goldberg, A. L. \& Dice, J. F. (1974). A. Rev. Biochem. 43, 835.

Marceau, N. \& Aspin, N. (1973). Biochim. biophys. Acta 293, 338.

Nordberg, G. F., Piscator, M. \& Lind, B. (1971). Acta pharmac. tox. 29, 456.

Porter, H. (1974). Biochem. biophys. Res. Commun. 56, 661.

Pulido, P., Kägi, J. H. R. \& Vallee, B. L. (1966). Biochemistry, Easton 5, 768.

Richards, M. P. \& Cousins, R. J. (1975). Bioinorg. Chem. 4, 2 I 5.

Rotilio, G., Calabrese, L., Bossa, F., Barra, D., Agro, F. \& Mondovi, B. (1972). Biochemistry, Easton Ix, 2 I 82.

Rupp, H. \& Weser, U. (r974). FEBS Lett. 44, 293.

Shapiro, J., Morell, A. G. \& Scheinberg, I. H. (1961). F. clin. Invest. 40, 1081.

Terao, T. \& Owen, C. A. Jr (1973). Am. F. Physiol. 224, 682.

Webb, M. (1972). Biochem. Pharmac. 21, 2751.

Williams, R. B. \& Mills, C. F. (1970). Br. F. Nutr. 24, 989.

Winge, D. R., Premakumar, R., Wiley, R. D. \& Rajagopalan, K. V. (1975). Archs Biochem. Biophys. r70, 253 .

Winge, D. R. \& Rajagopalan, K. V. (1972). Archs Biochem. Biophys. 153, 755. 